\title{
高輝度マイクロチップレーザーとエンジン点火
}

\author{
平等 拓範 \\ 分子科学研究所 ( T444-8585 愛知県岡崎市明大寺町字西郷中38番地)
}

High Brightness Microchip Laser and Engine Ignition

\begin{abstract}
Takunori TAIRA
Laser Research Center for Molecular Science, Institute for Molecular Science, 38 Nishigonaka, Myodaiji, Okazaki, Aichi 444-8585
\end{abstract}

(Received June 16, 2010)

\begin{abstract}
A passively $Q$-switched Nd:YAG/Cr:YAG microchip laser was developed. The output energy of $3 \mathrm{~mJ}$ per pulse (totally $12 \mathrm{~mJ}$ for 4 pulses) was obtained with the optical-to-optical efficiency of $19 \%$. The pulse width and $M^{2}$ value were $500 \mathrm{ps}$ and 1.2, respectively. The brightness of the microchip laser was calculated to be $0.3 \mathrm{PW} / \mathrm{sr}-\mathrm{cm}^{2}$ and the optical power intensity of $5 \mathrm{TW} / \mathrm{cm}^{2}$ was estimated at the focal point of ignition. A $100 \%$-ignition was successfully demonstrated by a five-pulse train in a lean mixture of an A/F 17.2, where spark plug ignition failed. Finally, ignition tests for a real automobile engine were performed. A single laser pulse with an energy of $2.3 \mathrm{~mJ}$ could ignite and drive the engine stably. It will be lowest energy ever reported for laser ignition of a real automobile engine. We can confirm that an optimally designed, high-brightness, passively $Q$-switched microchip laser reduced the ignition energy dramatically compared with previous ignition lasers and a spark plug and the dimension of the laser head can be reduced to real spark plug size.
\end{abstract}

Key Words: Passively $Q$-switched microchip lasers, Nd:YAG, Cr:YAG, Laser ignition, Micro solid-state photonics

1.はじめに

化石エネルギーの大量消費による資源枯渇と地球温暖 化，気象変動を含めた環境破壊は今や大きな社会問題と なり，低炭素社会構築のための代替エネルギーおよびエ ネルギー変換研究に高い期待が寄せられている. 特に我 が国は, 一次エネルギーの9割を石炭, 石油, 天然ガス に依存しており，エネルギー変換法としての燃焼方式の 高効率化, 低エミッション化の実現は内燃機関 (エンジ ン)を有する自動車, 発電機において大きな課題であ る。これはハイブリッド車でも状況は同じでエンジンの 要求はますます厳しくなり, 次世代高性能エンジンのた めに制御性の高い点火法が求められている。このような 中，高尖頭出力レーザーを用いた混合気の着火法である レーザー点火では，非接触かつ時間・空間的な自由度が 高いためシリンダー内での理想的な燃焼状態を作り出せ るとされ，プラグに代わる点火装置として期待が寄せら れている ${ }^{1,2)}$. しかしながら, 尖頭值がメガワット以上 のジャイアントパルス固体レーザーは，一般に大型・不
安定で効率も低いため研究室から持ち出す事ができず レーザー点火は単なる基礎研究に留まっていた。一方, 近年のマイクロ固体フォトニクスの進展は, 従来とは異 なった視点から高輝度光を創り出せるもので, 新たな学 術分野の創出にとどまらず，産業応用も望めるなど，そ の期待は高い ${ }^{3-5)}$. 本稿では, 最新の高輝度マイクロ チップレーザー*に関し, 自動車におけるフォトニクス 展開との観点からエンジン点火を中心に一連の研究を紹 介したい ${ }^{6-10)}$.

\section{2. 高輝度マイクロチップレーザー}

\section{1 自動車におけるフォトニクス}

最近になりFig. 1に示されるように光科学技術(フォト ニクス)の自動車分野への応用が進んでいる，レーザー による切断, 溶接, 微細加工は今や車体の軽量化と強度 向上に不可欠であるが，それ以外でも白色LEDによる ヘッドランプは，すでに高級車を中心に搭載が始まって いる。また車載カメラにはこれまで主要であったバック

* 本稿では各部品を独立に配置したマイクロレーザーも, 最終的には単体のマイクロチップを目指していることから, 総称してマ イクロチップレーザーと呼ぶことにする. 


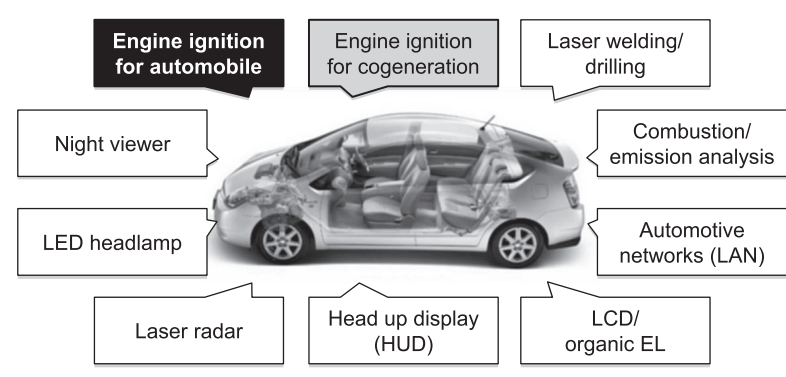

Fig. 1 Photonics for automobile.

モニタからサイドモニタ, フロントモニタなどの視覚確 保用カメラシステムや, 車線検知システムを応用したア ダプティブクルーズコントロール等が開発されており, さらには近赤外線カメラを用いて夜間の歩行者検出を行 うナイトビュアーや衝突防止のレーザーレーダーなども 一般的な安全装置として導入が検討されつつある。ま た, 液晶ディスプレイ (LCD) や有機ELによるメー夕類 の表示も進んできているが, さらに各種レーザーディス プレイのヘッドアップディスプレイ(HUD)への展開な ども検討が始まっている。 その他, 運転のモニタに加え 赤外線レーザーによる然焼や排気ガスの解析などの提案 もある. 加え, 近年の自動車はそのインテリジェント化 が急ピッチに進められており，このため数10個から，多 い場合で100個以上の電子デバイス $(\mathrm{ECU})$ が必要となっ てきた。そしてECUの増加に従い配線も複雑かつ膨大と なり, ついに車内スペースの占有や車重の増大が無視で きないレベルになってきた。そのため金属配線を光ファ イバによる光LANに代えることで軽量化, 省資源化が 図られている。このようにフォトニクスは自動車の様々 な領域で欠かせない要素となっているが, その根幹であ る動力・エネルギーに直接かかる話題はこれまで出てこ なかった．当然ながらこの様な話題には金属加工やブレ イクダウンを引き起こせるようなジャイアントパルス固 体レーザーが求められるが, これらは一般に大型かつ不 安定で, さらに大容量電源や水冷装置などが必要であり 車載は想像することすら困難であった。 また装置も高価 であり誰もがまともな議論ができるようになるとは思わ れなかった，そのため天然ガスによる発電システムなど の設置型の大型内燃機関を中心に, 特に欧米において精 力的な研究が進められてきた. しかし, 種々の問題のた め基礎研究に留まってきた ${ }^{1-3)}$. それがマイクロ固体 フォトニクスの進歩により事情が急変した。驚くことに マイクロチップ化がレーザーの高性能化に繋がり, 種々 の困難を克服しつつある.

\section{2 受動 $Q$ スイッチ型マイクロチップレーザー}

共振器の良好指数 (quality factor) である $Q$ 值を短時間 に切り換えることで，レーザー媒質中に蓄積された反転 分布エネルギーを瞬時に取り出し，ジャイアントパルス 発生を可能とする $Q$ スイッチ動作は, 長い蛍光寿命を有 する固体レーザーの特長とされている。ここでは，マイ クロ固体レーザーの短共振器性を損なわない可飽和吸収
体 (saturable absorber: SA)による受動 $Q$ スイッチ法 ${ }^{12)} に つ$ いて考察する (Fig. $2(\mathrm{a}))$. この場合, 励起光 $h v_{\mathrm{p}}$ により 発光中心の電子状態が上準位に励起され，次いで下準位 への遷移により光子 $h v か ゙$ 輻射される，共振器内の光子 密度が低い初期状態ではSA吸収が強く, 共振器損失が 大きいためレーザー発振には至らない。しかし励起を続 けることで，上準位分布密度が蓄積され，利得が増大， 初期損失に打ち勝つ事でSA下準位の電子密度が減少, 吸収が飽和し，急激なパルス成長が促されジャイアント パルス発生に至る.

解析的には, $\mathrm{SA}$ 初期透過率を $T_{0}$, 飽和後の透過率 $T_{\mathrm{f}}$ とした場合の出力パルスエネルギー, パルス幅は

$$
\begin{gathered}
E_{p}=\frac{h v \cdot A_{g}}{2 \gamma_{g} \sigma_{g}} \ln \left(\frac{1}{R}\right) \ln \left(\frac{n_{g i}}{n_{g f}}\right) \\
\tau_{p}=\frac{\ell_{c}}{c} \ln \left(\frac{n_{g f}}{n_{g i}}\right) \frac{p}{\ln T_{0}} \frac{1}{Z}
\end{gathered}
$$

で与えられる ${ }^{13,14)}$.このとき，

$$
\begin{aligned}
Z=1 & -\frac{n_{g t}}{n_{g i}}+[1+(\delta-1) p] \ln \left(\frac{n_{g t}}{n_{g i}}\right) \\
& +\frac{p}{\alpha}(\delta-1)\left[1-\left(\frac{n_{g t}}{n_{g i}}\right)^{\alpha}\right]
\end{aligned}
$$

また, $\alpha=\gamma_{S A} \sigma_{S A} A_{g} / \gamma_{g} \sigma_{g} A_{S A}, \quad p=2 \ln T_{0} /\left(\ln R+2 \ln T_{0}-L_{g}\right)$, $\delta=\sigma_{E S A} / \sigma_{S A}$ である。なお， $A_{g}, A_{\mathrm{SA}}$ はレーザー媒質, SA でのレーザー光有効面積, $\gamma_{\mathrm{g}}, \gamma_{\mathrm{SA}}$ は縮退による各々の反 転分布減衰因子， $\sigma_{\mathrm{g}}$ はレーザー媒質の誘導放出断面積, $\sigma_{\mathrm{SA}}, \sigma_{\mathrm{ESA}}$ はSAの吸収断面積及び励起状態吸収(excited state absorption: ESA) 断面積である。さらに， $T_{0}, T_{\mathrm{f}}$ は $\mathrm{SA}$ の初期透過率と飽和透過率, $\mathrm{Lg}$ は共振器残留損失で あり， $n_{\mathrm{gi}}, n_{\mathrm{gt}}, n_{\mathrm{gf}}$ は, それぞれ発振開始時, 発振終了 時, 出力ピーク時の反転分布密度であり, $n_{\mathrm{gf}}$ と $n_{\mathrm{gi}}$ の比及 び $n_{\mathrm{gt}}$ と $n_{\mathrm{gi}}$ の比を求める事で, 受動 $Q$ スイッチレーザーの パルスエネルギーとパルス幅が解析的に得られることが

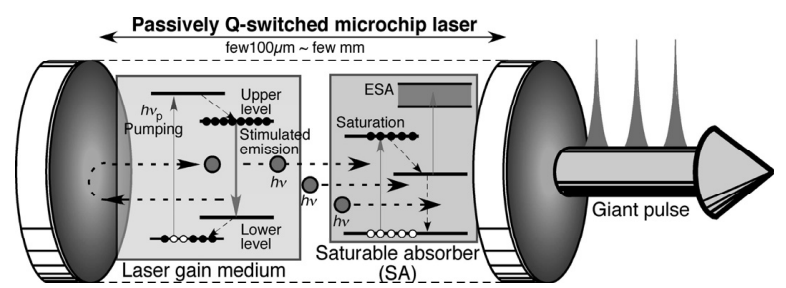

(a)

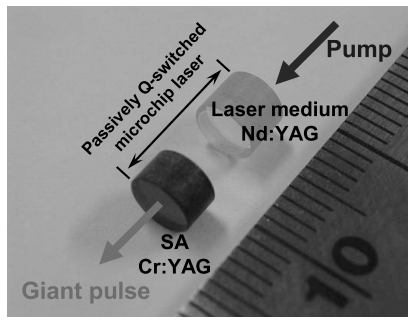

(b)

Fig. 2 Model of passively $Q$-switched microchip lasers (a) and photograph of components (b). 
示された

まず，出力エネルギーについて考察する。式(1)より レーザー出力鏡の反射率を下げ，レーザー媒質における ビーム面積を広げるとともに, 反転分布については初期 值を高く，動作終了時のそれを低くする事がパルスエネ ルギー増大には有効であることが分かる．分光学的には 誘導放出断面積が小さく, 蛍光寿命の長いレーザー材料 が高エネルギー化には適している事になる。輝度の観点 からは, 式(1)より横モード品質 $M^{2}$ 值は劣化させずに出 力エネルギーを増大させると共にパルス幅を短くすべし との方針が得られる。一方, 式(2)からレーザー共振器 長を短くする事は，短パルス化に直接寄与する事が，ま た, 式(1)からは, その事自体は出力エネルギー劣化に 繋がらない事が分かる. Fig. 3 (a) にレーザー媒質とし てNd: $\mathrm{YAG}\left(\mathrm{Nd}^{3+}: \mathrm{Y}_{3} \mathrm{Al}_{5} \mathrm{O}_{12}\right)$ を, SAとして $\mathrm{Cr}^{4+}: \mathrm{YAG}$ 用い た受動 $Q$ スイッチ型レーザーにおける出力エネルギーの 可飽和吸収体初期透過率特性を, Fig. 3 (b) にパルス幅 の共振器依存特性を示す。これら計算及び実験の両面か ら上記考察の妥当性が検証された. さらに, 受動 $Q$ ス イッチ動作のための可飽和吸収体は, 他の $Q$ スイッチ法 に比べ小型・簡便化が図れるだけでなく, 共振器内に あってはソフトアパーチャとして機能するため $M^{2}$ 值改 善にも効果がある.

Fig. 2 (b) に，実験に用いた受動 $Q$ スイッチマイクロ チップレーザーの主要部を示す ${ }^{14)}$. 最終的には, レー ザー媒質(長さ5 mmの1.4 at.\% Nd:YAG) と $Q$ スイッチ用 $\mathrm{SA}$ (初期透過率30\%のCr:YAG) を接合し全長 $8 \mathrm{~mm}$ の一体 構成とし, $\mathrm{Cr}: \mathrm{YAG}$ の出射面には反射率 $R=56 \%$ の部分 反射率, $\mathrm{Nd}: \mathrm{YAG}$ 面には励起光に高透過率, レーザー光 に高反射率の誘電体多層幕コーティングを施した。励起 には，コア径 $400 \mu \mathrm{m}, N A=0.22$ で波長 $808 \mathrm{~nm}$ のフィ バ出力半導体レーザー (laser diode: LD) 光を倍程度に拡 大し, Nd:YAG端面より入射し用いた。 ところで, 受動 $Q$ スイッチでは, 励起パワーの増大によりレーザー出力
は増大するものの，パルスエネルギーは増大しない. 代 わりに繰返し周波数が上昇する ${ }^{13)}$ 。 また，ジッターも大 きく制御性に欠ける。そこで，LDを $100 \mathrm{~Hz}$ で変調制御 することで繰返し周波数を固定することとした，駆動電 流パルス幅は, $420 \mu \mathrm{s}$ と蛍光寿命の約 2 倍にすることで 発振の安定化を図った。LDからの励起パルスパワーは $28 \mathrm{~W}$ と, 平均光電力を $1.2 \mathrm{~W}$ に抑え空冷を可能とし た.この結果, 最大で出力エネルギー $0.67 \mathrm{~mJ}$ を得た. パルス幅は400 psとサブナノ秒であったため尖頭出力に して1.7 MWとメガワット出力を達成した。なお，一体 化せず，最適動作を図ったときは最大で $0.97 \mathrm{~mJ}$ ，パル

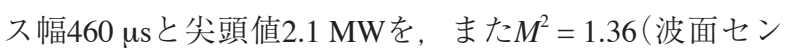
サー, WaveFront社CLAS-2D) を得た。輝度にして

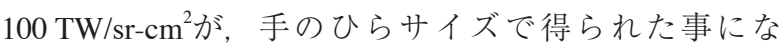
る。また，スペクトル幅は $5 \mathrm{pm}$ 以下と，測定に用いた ファブリーペロー干渉計(Burielgh社, WA-4550型)の分 解能限界で制限された。輝度温度では少なくとも62 EK $\left(6.2 \times 10^{19} \mathrm{~K}\right)$ にもなり, 太陽の $10^{16}$ 倍もの輝度温度光が 手のひらサイズ，パルス当り消費電力 $12 \mathrm{~mW}$ で非常な低 消費電力で達成できたことになる ${ }^{14)}$.

\section{3 波長変換とレーザー加工特性}

このような高輝度温度の光は非線形光学波長変換に適 しているが，Nd:YAGが立方晶系のレーザー材料である ため高出力動作時には圧縮応力による偏光制御 ${ }^{12)}$ が効か ず，安定した直線偏光が得られず深刻な問題となってい た。一般に用いられる[100]カットCr:YAGでは $90^{\circ}$ 毎に ほぼ同程度の透過率ピークが現れ，2つの偏光方向が許 容されるため不安定となるためである。しかし, Fig. 4 (a)に示す配置で初期透過率 $25 \%$ のr:YAG [001]軸に対 し光強度 $400 \mathrm{MW} / \mathrm{cm}^{2}$ と非飽和時の透過率偏光角度依存 性を調べたところ, 同図(b)に示すように に゚と $90^{\circ}$ の透 過率に過渡的には差が生ずる事を見出した ${ }^{15)}$ 。この場 合, 一方の偏光成分を選択成長できるため, 高出力動作

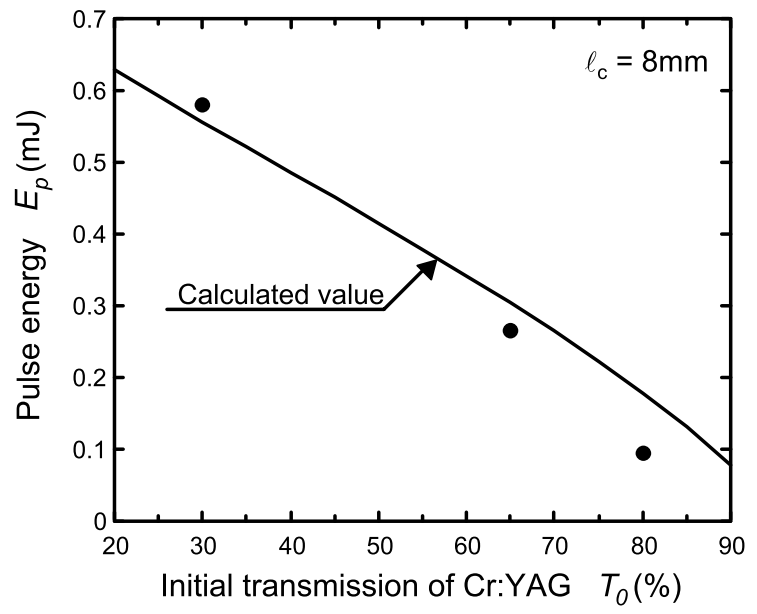

(a)

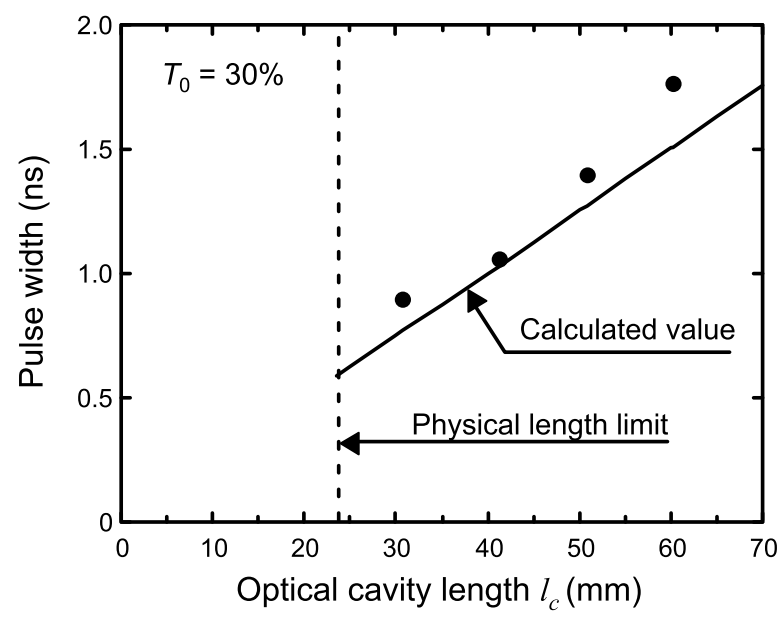

(b)

Fig. 3 Output pulse energy as a function of initial transmission (a) and pulse width as a function of cavity length (b). Where $\sigma_{\mathrm{g}}=2.3 \times 10^{-19} \mathrm{~cm}^{2}, \sigma_{\mathrm{SA}}=4.3 \times 10^{-18} \mathrm{~cm}^{2}, \sigma_{\mathrm{ESA}}=8.2 \times 10^{-19} \mathrm{~cm}^{2}, \gamma_{\mathrm{g}}=2$ and $\gamma_{\mathrm{SA}}=1$. And design parameters $\mathrm{A}_{\mathrm{g}}=\mathrm{A}_{\mathrm{SA}}=2.0 \times 10^{-3} \mathrm{~cm}^{2}\left(\mathrm{w}_{\mathrm{p}}=370 \mu \mathrm{m}\right)$ and $\mathrm{L}_{\mathrm{g}}=1 \%$. 
時においても安定な直線偏光が得られ, 高効率な波長変 換が可能となった. この受動 $Q$ スイッチ型マイクロチッ プレーザーの出力 $(600 \mu \mathrm{J})$ をそのまま長さ $10 \mathrm{~mm}$ の Type I位相整合 $\mathrm{LiB}_{3} \mathrm{O}_{5}(\mathrm{LBO})$ に入射することでパルス幅 約 $400 \mathrm{ps}$ ，出力 $300 \mu \mathrm{J}$ の第二高調 $(\mathrm{SH})$ 波 $(532 \mathrm{~nm})$ を得た (集光しなくともSHG変換効率は約50\%に及ぶ). この 数 $100 \mathrm{~kW}$ 尖頭出力の緑色光を, 焦点距離 $110 \mathrm{~mm}$ のレン ズで約 11 um直径まで絞り込んだところステンレス鋼 (SUS304)への微細穴開けが確認された.Fig. 5 (a)に $300 \mu \mathrm{m}$ 厚までのSUS304におけるアブレーション特性を, また, 同図(b)に $25 \mu \mathrm{J}\left(23 \mathrm{~J} / \mathrm{cm}^{2}\right)$ のパルスにより $100 \mu \mathrm{m}$ 厚のSUS304をドリル加工した際の裏面写真を示す。こ れによりマイクロ共振器由来のジャイアントパルス光 は, 高効率波長変換や良好な金属加工も望めるまでに高 輝度化されている事が検証された。ささらには，LBOを用 いた三倍波発生による紫外光(波長 $355 \mathrm{~nm}$ ) やBBOによ る四倍波発生(波長 $266 \mathrm{~nm}$ ), PPMgLN (耐光損傷のため $\mathrm{MgO}$ 添加）による高効率，高機能光パラメトリック発生 による中赤外光, またMgLNによるテラヘルツ波(波長 100 330 $\mu \mathrm{m}$ ) 発生 ${ }^{16)}$ にも成功しており排気ガスや浮遊粒 子状物質 (suspended particulate matter: SPM)の診断などへ の展開が期待されている。そして，このような背景か

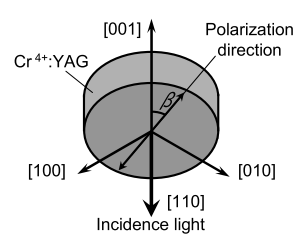

(a)

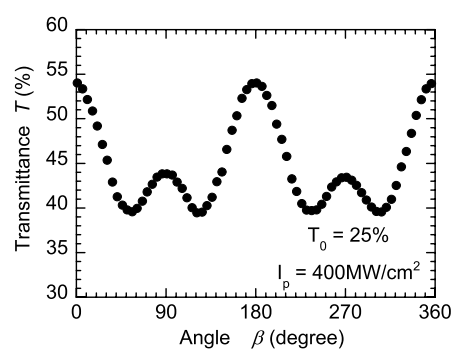

(b)
Fig. 4 Relation between the polarization direction and the crystallographic axes (a) and dependence of the transmission of [110]-cut $\mathrm{Cr}^{4+}$ :YAG single crystals (b).

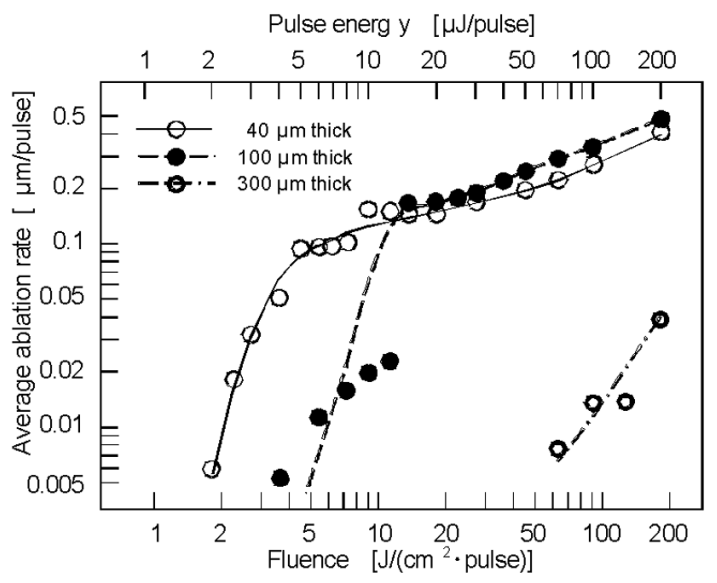

(a)
ら，マイクロチップレーザーの高輝度性に着目した新た な自動車フォトニクスの議論が始まった。

\section{3. エンジン点火特性}

\section{1 レーザー点火の特長}

19世紀半ばに登場したガソリンエンジン車は，燃料と して高いエネルギー密度を有する事からこれより以前に 提案された蒸気自動車や鉛蓄電池式電気自動車を淘汰し てきた。そして現在もハイブリッドカーを含め低排出, 低燃費の小型高出力エンジンを目指し，その特性改善が 精力的に進められている。ここで注目すべきは，ガソリ ンエンジンの点火方式である。 スパークプラグの電極間 で絶縁破壊を起こし，約6,000 Kの高温の小さな熱プラ ズマを放電ギャップ間に形成する手法は，スパークプラ グの誕生以来100年以上もの間，基本的には変わってい ない.しかし，現在普及しているスパークプラグによる 電気火花点火 (Fig. 6 (a))では, 電極による冷却効果に より火炎核形成時の燃焼エネルギーの消失が50\%以上 と大きいこともまた良く知られている. 加えて, 構造的 な問題から燃焼室中央で点火することが困難であり，さ らに電極が燃焼室内部に突き出た異物となって，シリン ダー内で理想的な高効率燃焼状態を作り出すことには限 界がある。燃料の利用効率低下と不完全燃焼が原因と なって，発生する一酸化炭素や窒素酸化物の排出を低減 する事は困難な状態であり，低NOx，低燃費の観点から ガソリンエンジンの超希薄燃焼の実現が望まれる。しか し，従来のスパークプラグによる点火手法では，制御性 がそしく，希薄燃焼限界の拡大に向け点火方式の革新が 切望されている17).

上記手法に対しレーザー点火 (Fig. 6 (b))ではそもそ も電極が不要で，空間的に自由度が高いため燃焼室中央 付近で点火することが可能となり，火炎が冷たい燃焼室 壁から受ける損失が小さく高効率な燃焼を促進できる. さらに，レーザー光の照射方式によってはシリンダー内 で多点での同時点火も可能で，燃焼時間の短縮と燃焼効

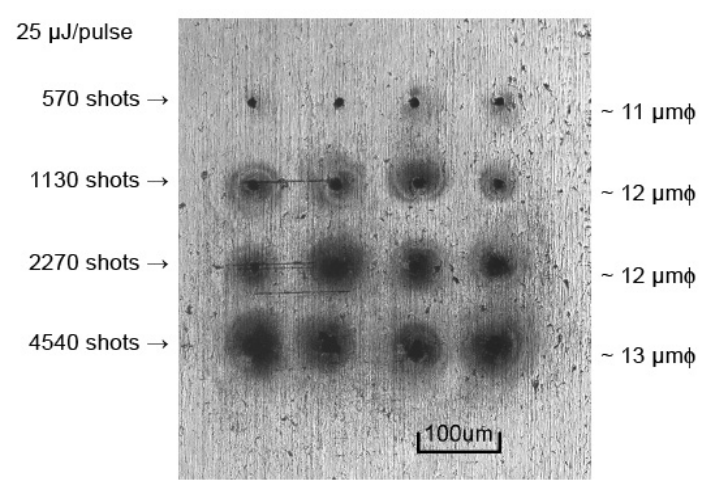

(b)

Fig. 5 Average ablation rate for pulse energy and fluence (a) and photograph of drilled 100- $\mu$ m thick SUS304 back surface measured by laser scanned micro-scope (b) (wavelength: $532 \mathrm{~nm}$ ). 


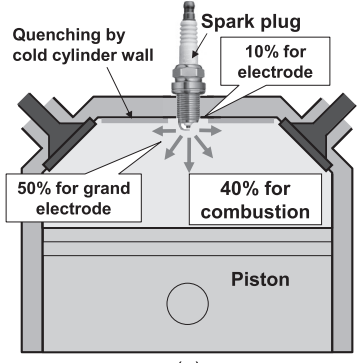

(a)

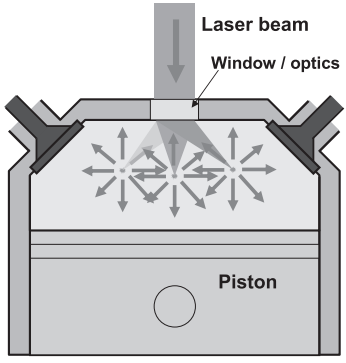

(b)
Fig. 6 Schematics of the combustion engines ignited by (a) a spark plug and (b) laser based multi-point breakdown.

率の大幅な改善が期待される。燃焼効率の改善は単に現 行のエンジン出力向上だけでなく, 燃費の低減, 希薄な 可燃性予混合気への点火が可能になる点が注目される。 さらにレーザー点火の大きな利点として，プラグでは点 火が難しい高圧の可然性予混合気に対しても着火が可能 である点が挙げられる。このため10年以上前よりレー ザー点火の有用性は世界の著名な研究機関から提案さ れ, 種々の検証が為されてきた。 そして, 可燃性予混合 気中でブレイクダウン(絶縁破壊)を起こしてガスに着火 させるためには, 集光点での光強度としておよそ $100 \mathrm{GW} / \mathrm{cm}^{2}$ が，また，安定した燃焼状態を可能とする には20 mJ以上のエネルギーが必要とされる等の諸特性 が明らかになり, 自動車用エンジンへのレーザー点火の 適用は余り現実的で無いと考えられるに至った。しか し，本当に不可能なのであろうか? 我々は，あくまでも 自動車エンジンに搭載する事を念頭にブレイクダウンの 基礎に立ち返り検討を行った。

\section{2 レーザーブレイクダウン点火}

レーザー点火としては, 一光子過程により生成された 化学種によって点火させる光解離点火法と, 強力なレー ザー光を未燃混合気に集光, ブレイクダウンにより生成 される高温プラズマを用いて点火させるレーザーブレイ クダウン法に大別される. 両者とも興味深いが, 後者は 多光子過程によるためレーザー波長を選ばず，また任意 の集光位置での点火が可能などエンジン点火に適した特 長を有する. Fig. 7にレーザーブレイクダウン点火の過 程を示す．まず未燃混合気中にレーザーを集光すること で多光子吸収過程で電離 (イオン化)させ, その放出され た自由電子を強い電界(集光されたレーザー光)で加速し (逆制動放射) 他の分子に衝突，電離させ (電子衝突電離) カスケード的に電子密度を高めて行くことでプラズマが 生成される. 結果として生じた高い電子数密度のプラズ マが更にレーザー光の吸収を高め, 電子密度の増加, 急 激な温度上昇をもたらし衝撃波を生成する。その残りの エネルギーで火炎核が形成される。火炎核は特有の流動 形状を保ち, 周りの未燃ガスを巻き込みながら燃焼領域 を広げて行く ${ }^{1,2}$.

ところで, 多光子吸収の確率は, 同一エネルギーであ ればパルス幅が短くピーク出力が大きいほど高くなる。

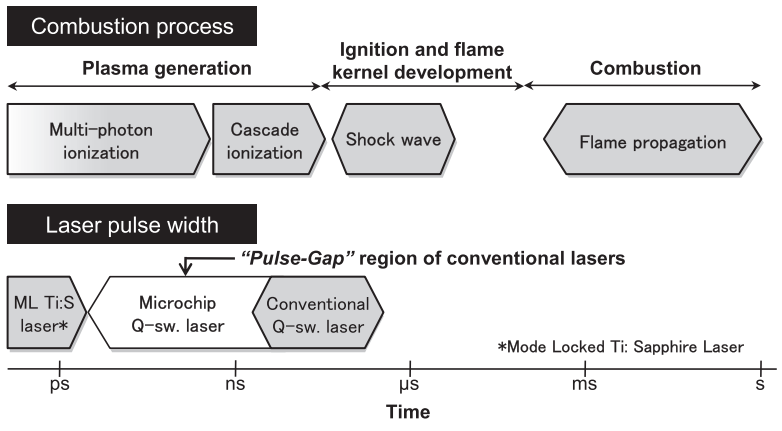

Fig. 7 Time scale of ignition by laser induced breakdown.

一方, 電子衝突電離は電子加速と衝突電離を連鎖的に起 こして行くため, 強電界に保持される時間が長いほどそ の確率は大きくなる。すなわち, 適したパルス幅のレー ザーを選ぶことで効果的な点火が可能になる。ところ で，レーザーブレイクダウンにはジャイアントパルスが 適している事から $Q$ スイッチNd:YAGレーザーが用いら れることが多いが，一般には，ビーム品質は悪く，輝度 (付録参照) は余り高く無くパルス幅は10 nsとナノ秒 (ns: $\left.10^{-9} \mathrm{sec}\right)$ 程度となる。 また, 尖頭出力を高くするために はモード同期 (ML: mode locking) 法が最適でTi:S (Ti: Sapphire) レーザーの出現によりフェムト秒 $\left(\mathrm{fs}: 10^{-15} \mathrm{sec}\right)$ が切り開かれたが，パルスエネルギーを高くすることは 困難で, 発振器レベルで比較するならパルスの尖頭出力 はQスイッチ法に比べ低くなるのが一般である。すなわ ちエネルギーが決定的に不足する。そして，実はピコ秒 (ps: $10^{-12} \mathrm{sec}$ ) 領域の良い光源が無かったため, この時 間領域のレーザーブレイクダウンに関する研究は進んで いなかった。一方, マイクロチップレーザーにおける $Q$ スイッチでは, Fig. 3 (b) からも分かるように共振器を 短くする事で従来のパルスギャップ(pulse-gap) 時間域へ

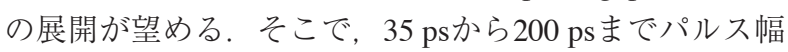
を可変のモード同期レーザー (波長 $532 \mathrm{~nm}$ ) を準備し, それらの最小ブレイクダウンエネルギーを調べた (Fig. 8). ナノ秒レーザーの中で最小絶ブレイクダウン エネルギーが最も小さいものでも $0.8 \mathrm{~mJ}$ 程度であった事 と比べ, 実験では0.24 0.36 mJ と非常に小さな值を示し た。しかもパルス幅が $200 \mathrm{ps}$ と 100 psでは最小絶縁破壊 エネルギーに大きな変化は無いものの, さらに短くなる と増大する事も分かった。一般にパルス幅が短くなれば 尖頭出力を高く取れるため最小ブレイクダウンエネル ギーも小さくなると思われるが，35２00 psの実験範囲 ではそれとは逆の傾向が得られた。今回の実験範囲で は, 短パルス化に伴う電子衝突電離確率低下の効果が, ピーク出力増大による多光子吸収確率増加の効果より大 きく, 最小ブレイクダウンエネルギーが増大したと考え られる。以上のように点火用レーザー光源として実用的 なナノ秒〜ピコ秒領域では，短パルス化が必ずしも最小 ブレイクダウンエネルギー，ひいては点火エネルギー低 減には繋がらない事が分かった。結果, 実用的な点火用 レーザー光源として従来は余り注目されなかった数 $100 \mathrm{ps}$ 領域が適していることが，また，短い共振器によ 


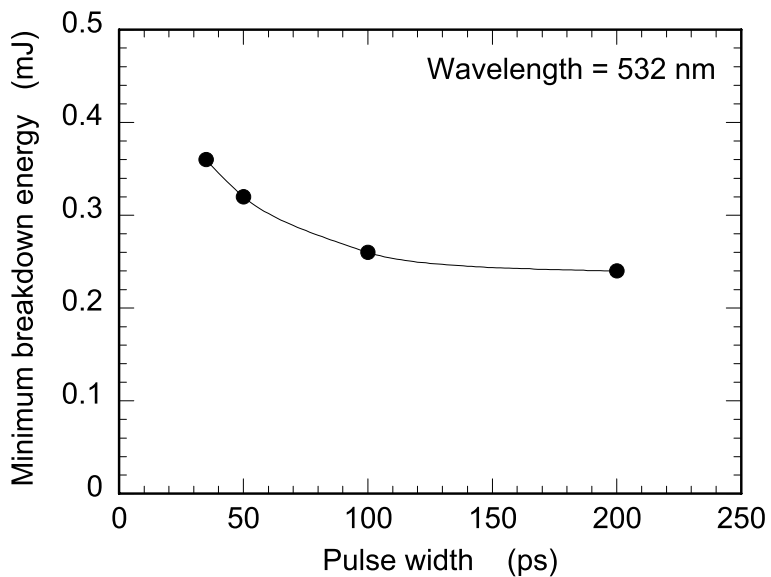

Fig. 8 Minimum breakdown energy as a function of laser pulse duration.

るQスイッチ型マイクロチップレーザーが点火に大変適 している事が明らかになっだ,8).

3.3 エンジン点火用高輝度マイクロチップレーザー

次に, 火炎核成長のためのエネルギー投入法について 考察する. 原理的にブレイクダウン以前の入射エネル ギーは点火に寄与せず透過することから, 従来のナノ秒 パルスによる点火ではFig. 9 (a)のように半分近くのエ ネルギーが点火に寄与せず透過するのに対し，サブナノ 秒での適切な間隔で多重パルスを入射する場合, ブレイ クダウンエネルギーの最小化と第二パルス以降への効率 的なエネルギー注入が見达めるため, 同図(b)のように その損失を $(1 / n)$ に抑える事も望める。これはパルス当 たりの入射エネルギーを小さくできるためレーザーやエ ンジン周りの光学系の負荷を低減できる。すなわち, 多 重点火では

1）点火に寄与するエネルギーの向上 (エンジンの高効 率化・高出力化)

2）エンジン負荷に応じた点火力のデジタル制御が可能 (エンジンの高性能化)

3) レーザーの動作電力や熱問題の低減 (光源仕様の緩 和・簡単化)

4) エンジン室への入射空など光学系への負荷低減 (全 体装置の高信頼化・長寿命化)

などの特長が期待できる。これを受け，レーザーブレイ クダウンにおけるプラズマ強度に及ぼすダブルパルスの 影響を実験的に評価した。その結果，パルス間隔が $100 \mathrm{~ns}$ 以下，もしくは1 us以上であれば多重点火が有効

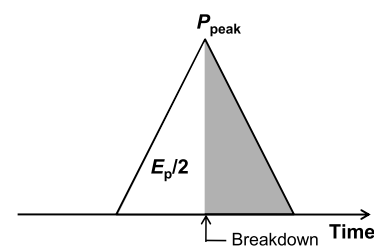

(a)

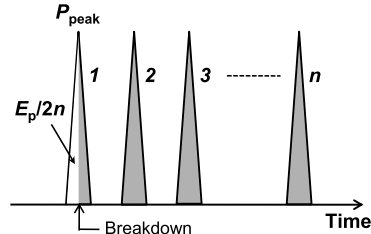

(b)
Fig. 9 Model of laser breakdown with single pulse (a) and multiple pulses (b) for ignition.
であることが分かった ${ }^{8)}$.

上記の事柄を踏まえ，まずは基本特性を把握するた め, 長さ $4 \mathrm{~mm}$ の1.1 at.\% Nd:YAGとCr:YAGを一体化せず, マイクロチップレーザー構成として長さ $10 \mathrm{~mm}$ の共振器 内部に配置した。励起には，コア径600 $\mu \mathrm{m}, N A=0.22$ のファイバ出力型の出力 $120 \mathrm{~W}$ の $\mathrm{LD}$ (波長 $\lambda_{\mathrm{p}}=808 \mathrm{~nm}$,

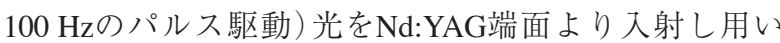
た。この構成に，初期透過率30\%のCr:YAGを用いて1パ ルスの出力エネルギーとして最大 $3 \mathrm{~mJ}$, 光 - 光変換効率 として $19 \%$ を得た。パルス幅は500 psとサブナノ秒で あったため尖頭出力は $P_{p}=6 \mathrm{MW}$ に達した，また，横 モード品質も $M^{2}=1.2$ と良好であったため輝度にして $B=0.3 \mathrm{PW} / \mathrm{sr}-\mathrm{cm}^{2}$ に至る。 また，スペクトル幅は $5 \mathrm{pm}$ 以 下と，測定に用いたファブリーペロー干渉計 (Burielgh 社, WA-4550型)の分解能限界で制限されたため輝度温 度では少なくとも $T_{\mathrm{B}}=0.46 \mathrm{ZK}\left(4.6 \times 10^{20} \mathrm{~K}\right)$ にもる. ところで, 受動 $Q$ スイッチでは, 励起パルス幅が $100 \mu \mathrm{s}$ 増加する毎に新しいレーザーパルスが発生し出力エネル ギーは階段状に増加するため7パルスで $20 \mathrm{~mJ}$ 得た (Fig. 10). そこで, LD駆動電流パルス幅を500 us とし4 パルスを 100 ～ $120 \mu \mathrm{s}$ インターバルで発生させ合計 $12 \mathrm{~mJ}$ を得る構成とした。 これにより同一エネルギーを得るた めに要求されるLDの仕様が緩和でき, 制御装置の簡便 化などが可能となる ${ }^{6-10)}$.

\section{4 エンジン点火実験}

試作したマイクロチップレーザーを用いたプラグとの 燃焼比較実験を室温 $\left(25^{\circ} \mathrm{C}\right)$, 大気圧 $(100 \mathrm{kPa})$ の静止場 定容容器 (室約 $200 \mathrm{~cm}^{3}$ )にて行った。使用した燃料ガス はプロパン $\left(\mathrm{C}_{3} \mathrm{H}_{8}\right)$ で, 空気との質量混合比 $(A / F)$ は理論 空然比（ストイキ， $A / F=15.3$ ) とした。 Fig. 11に点火卜 リガー後6 msまでのシュリーレン撮影写真(高速カメラ, 毎秒25000フレーム)を示す。なお，レーザーからの合計 パルスエネルギーは $\mathrm{mJ}$ (3パルス合計)，プラグへの印 加電力は $35 \mathrm{~mJ}$ とし, 同じ観察位置, 同じ倍率で撮影し た，図のように点火 $6 \mathrm{~ms}$ 後においてレーザーの方がプラ グに比べ写真中火炎核が占める面積が約3倍大きい.

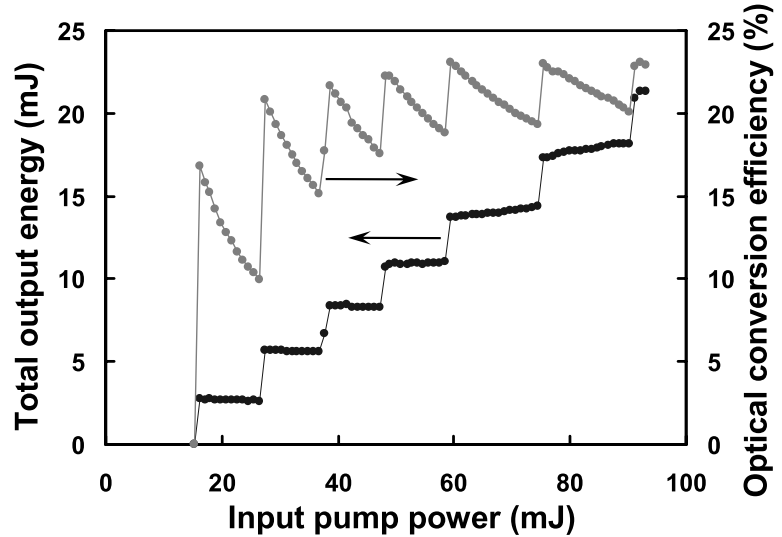

Fig. 10 Output-energy and optical-to-optical conversion efficiency of microchip laser as a function of pump duration. 


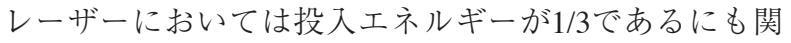
わらず，電極による冷却効果を受けないため火炎核の成 長がプラグに比べ著しく早いことを確認できた ${ }^{9)}$.

次に, 同じ定容容器を用いて空気の混合比を増やした リーン状態での燃焼の様子を調べた。まず， $A / F=15.2$ おいては，わずか $3 \mathrm{~mJ}$ おパルスエネルギーでも $100 \%$ の 着火確率が得られた。プラグの約 $1 / 10$ のエルギーで着 火できたことは，レーザー点火の優位性と同時に今回開 発したマイクロチップレーザーの優れた集光性とサブナ ノ秒多重パルスが点火に非常に有利に働いていることを 証明するものである。ささらに励起光パルス幅を長くし， パルス数を増やすことで, よりリーンな可然性予混合気

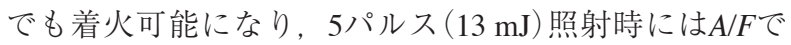
17.2 においても $100 \%$ 着火が実現されている. プラグの

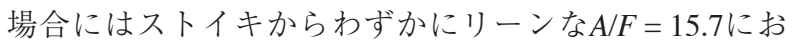
いても既に着火確率が100\%を切っており，もともと然 焼速度が遅い(着火しにくい)リーンな可燃性予混合気で は電極による冷却効果が, より悪影響を及ぼす様子が理 解できる ${ }^{9,10)}$.

比較燃焼実験より, 今回試作した小型高輝度受動 $Q$ ス イッチマイクロチップレーザーのエンジン点火用光源と しての実用性と優位性を確認した。次に，市販の2.0 L, 4気筒のガソリンエンジン1AZ-FSE (TOYOTA Motor Corp.)を用いた比較評価を行った。 ここではエンジン上 部に組んだ櫓に試作したマイクロチップレーザーを一台 配置し，4気筒の内1気筒を照射できる構成とした。繰り 返しは，エンジンの1600 rpmに対応すべく $13.3 \mathrm{~Hz}$ に設 定した. Fig. 12に従来のスパークプラグと比較したマイ クロチップレーザーによる点火特性のシュリーレン撮影 写真を示す。スパークプラグには $35 \mathrm{~mJ}$, マイクロチッ

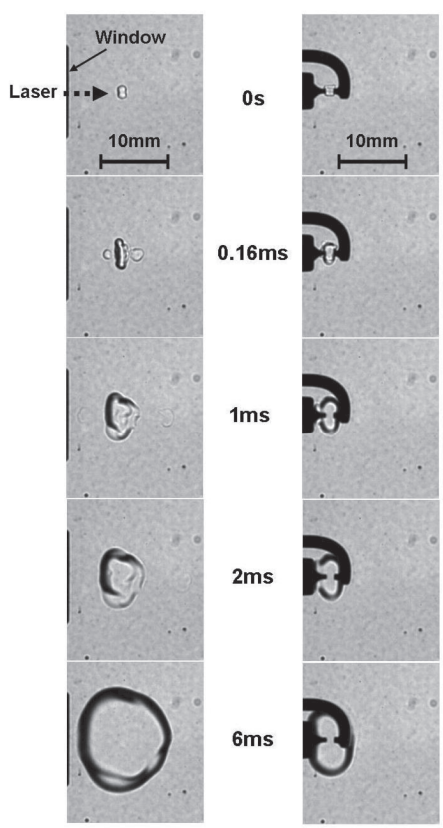

(a)

(b)

Fig. 11 Schlieren photography of the flame kernel ignited by a microchip laser (a) and spark plug (b) in a constant.
プレーザーは 1 パルス $2.3 \mathrm{~mJ}$ を投入し，A/F14.5での特性 を調べたところ，ほぼ同程度の燃焼特性を確認できた。

すなわち，高輝度マイクロチップレーザーでは，従来の スパークプラグに比べ約 $1 / 4$ の点火エネルギーでもプラ グと同程度のエンジン点火が可能であることを実証し $た^{8,10)}$.

\section{4. まとめ}

自動車におけるフォトニクスとの観点から，特にその エンジン点火を目指し受動 $Q$ スイッチ型マイクロチップ レーザーの高性能化を図ったところ，4パルス列動作に よる $12 \mathrm{~mJ}$ 出力を(パルスエネルギー $3 \mathrm{~mJ}$, 尖頭出力 $6 \mathrm{MW})$ ，また7パルス動作では合計 $20 \mathrm{~mJ}$ 達成した。縦 横モードも良好で輝度 $0.3 \mathrm{PW} / \mathrm{sr}^{-\mathrm{cm}^{2}}$, 輝度温度にして $0.46 \mathrm{ZK}\left(4.6 \times 10^{20} \mathrm{~K}\right)$ を得ており回折限界に近い集光が 可能となる. また輝度が高いからこそ, 大気中でのブレ イクダウンも確認でき, 定容容器静止場における混合ガ ス点火実験においては，通常のスパークプラグを上回る 性能が検証できた。また，実際の自動車エンジンに適用 しその優れた点火特性も実証できた。一方, マイクロ チップレーザーの小型化も進んでおり励起集光光学系, Cr:YAG/Nd:YAGなど一式を全長57 mmのプラグ型筐体に 造り込む事も行った(Fig. 13)。なお，写真の筐体には集 光レンズも内蔵されており大気中で安定なブレイクダウ ンが観測できる。一方で，その特性改善も進んでおり， これまでにパルスエネルギー $4 \mathrm{~mJ}, 4$ パルス合計 $16 \mathrm{~mJ}$ の 出力を光 - 光変換効率 $23 \%$ で得ている. また, パルス の時間幅も $300 \mathrm{ps}$ 程度にまで短くできるため, 尖頭值は 15 MWに至る。また，焼結法によるセラミック Nd:YAG/

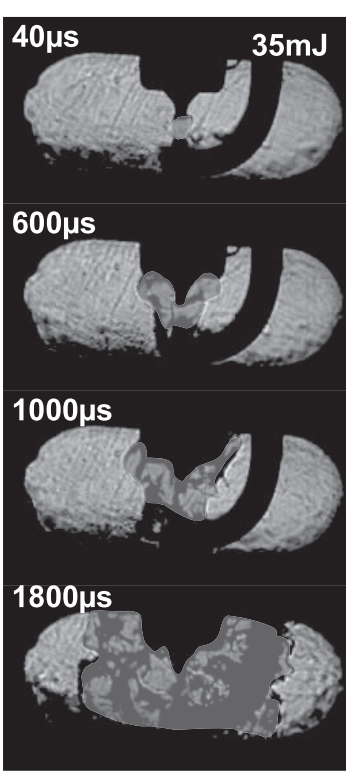

(a)

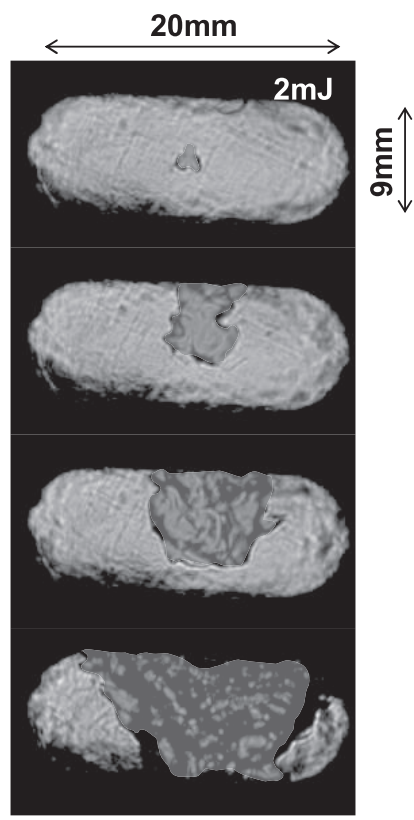

(b)
Fig. 12 Schlieren photography of the early stage of ignitions and combustions in \#4 cylinder by a spark plug (a) and microchip laser (b). 


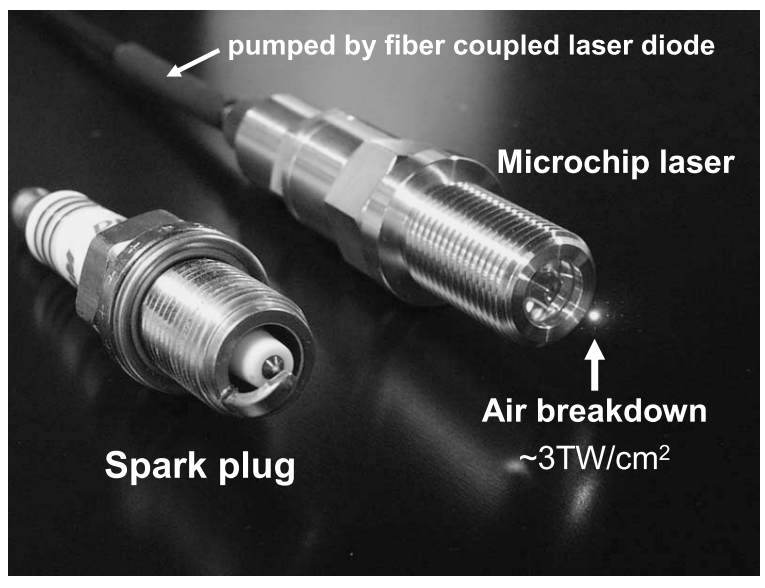

Fig. 13 Photograph of a prototype microchip laser head (oscillating) and spark plug.

Cr:YAGコンポジット材料 ${ }^{18)}$ の性能向上も著しく, 同様 の構成で上記值に匹敵する特性が得られつつあり将来の 量産化にも道が拓かれつつある。加えて, $100{ }^{\circ} \mathrm{C}$ を越え

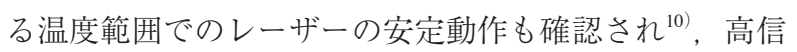
頼化も期待できるため, バイオ燃料車やハイブリッド車 を含めた次世代自動車エンジンの高性能化に有望であ る.

一方で，エンジン点火は天然ガスによる発電システム であるコジェネレーションが直面する点火スパークプラ グの問題を解決し, 高効率化, 長寿命化に繋がるともさ れる ${ }^{19)}$. また，ジャイアントパルスNd:YAGレーザーの $\mathrm{SH}$ 波 $(532 \mathrm{~nm})$ によるレーザーピーニング20) は, 定期点 検時に原子炉壁の強度改善ができるとして世界的にも注 目が集まっている.未処理のSUS404では応力腐食割れ が発生するもののレーザー照射による光の弾で材料を強 化することで腐食割れを防ぐことができる。しかし，こ れには大型のレーザーを用いた施工システムが必要とさ れ海外での普及を妨げていた，本稿で紹介したマイクロ チップレーザーは, 既に金属加工を可能としており, 原 子力発電所におけるピーニング用レーザーとしても期待 が高い.

以上, マイクロ固体フォトニクスの展開により可能と なったマイクロチップレーザー点火方式は, 化石エネル ギーの高度利用を可能とするもので近未来の低排出, 低 燃費の高効率・高出力自動車エンジンに期待されてい る。また，天然ガスや原子力などの魅力的な発電システ ムへの適用も検討が始まっている。一方で, 航空機など のように内燃機関が必須のシステムもあり，加えて，サ ブナノ秒の高輝度マイクロチップレーザーは非線形光学 波長変換やアブレーションも高効率に行えるもので, 可 視, 紫外から中赤外, さらにはテラヘルツ波発生におけ る励起光源や, 物質の微細加工用の光源としても有用性 が実証されており, 広い意味での自動車フォトニクスへ の展開が見込まれる. 今後, より多くの研究者の参加に よる精力的な研究・開発を期待したい.
謝 辞

本研究に関連しご協力，ご議論頂いた，ルーマニア国 立原子物理学研究所のNicolaie PAVEL博士, (株) 島津製 作所の齊川 次郎博士, 浜松ホトニクス(株)の酒井 博氏, 菅 博文博士, 分子科学研究所の常包 正樹博士, (株) 豊 田中央研究所の藤川武敏氏，蝦名 正輝氏，秋濱一弘 氏, (株) 日本自動車部品総合研究所の猪原孝之氏, 安藤 彰浩氏，木戸直樹氏，金原賢治氏らに感謝しま す。さらに，レーザー点火コジェネレーションに関して は産総研の古谷博秀博士, 原子炉のレーザーピーニン グに関しては(株) 東芝の佐野雄二博士から多くの情報 を頂いた。ここに感謝します。また，本研究は一部，文 部省科学技術振興調整費「輻射制御直接励起マイクロ チップレーザー」(平成14１6年度), 科学研究費地域連 携推進研究「界面制御による高機能光計測用広带域波長 可変クロマチップレーザーの開発研究」(No. 12792003), 科学技術振興機構育成研究「光波反応制御型内燃機関を めざしたマイクロレーザーの研究開発」(平成18年〜20 年)の補助を受けた。関係者各位に謝意を表する。

\section{付録 $A$ 輝度と輝度温度}

レーザー光を取り扱う際, 収差などを考慮しても計算 通りの集光径(スポットサイズ)が得られないことが多々 ある。これは, 多くのレーザー装置は高次横モードが混 入しビーム品質を劣化させているため回折限界光である ことを前提とした計算に乗らない事による。この様な混 乱を避けるため $M^{2}$ 因子を用いた標準化が進んでいる. $M^{2}$ 因子は, いわゆる積分表示であるため一部, 空間分 布に関する情報は失われるが，二次モーメントで定義さ れるビーム径および空間伝搬については正確な記述が可 能になる。.すなわち, この因子によりレーザーの集光特 性が記述できる。ささらには, 発光体の単位面積の明るさ である輝度 (brightness)を表す事も可能になる ${ }^{21)}$.

$$
B=\frac{P}{S \Omega}=\frac{P}{\left(M^{2} \lambda\right)^{2}}
$$

ここで, Pはレーザーのパワー, $S=\pi\left(d_{0} / 2\right)^{2}$ は面積, $\Omega=\pi(\Theta / 2)^{2}$ はその立体角である。輝度は単位立体角当 りの光度であり, 準単色光については強度に比例する. 定義式 $M^{2}=(\pi / 4 \lambda) d_{0} \Theta$ を考慮するなら, (A1) が容易に 導ける。レーザー光の特長は，コヒーレンスが高く，パ ワーが大きい事であろう。これはまた, 輝度温度 (brightness temperature)が高いとも表現できる，光源の 輝度温度とは, それと同じ輝度で熱放射する黒体の温度 と定義される。いま, 周波数 $v$, スペクトル幅 $\Delta v$ の, あ る偏りを持つ光を考え, それが同じスペクト範囲内の黒 体輻射 (温度 $T_{\mathrm{B}}$ ) と同じ輝度であるとする，黒体表面のあ る偏りを持つ単位面積当り, 単位立体角内に放出される 光のパワーは $c U(v) \Delta v / 8 \pi^{*}$ で与えられるから, 


$$
\frac{P}{S \Omega}=\frac{h v^{3}}{c^{2}\left\{\exp \left(h v / k_{B} T_{B}\right)-1\right\}} \Delta v
$$

が成立する。式 (A1)の関係とレーザー光の輝度温度が 極めて高い事を $\left(k_{B} T_{B}>>h v\right)$ 考慮するなら輝度温度は,

$$
T_{B}=\frac{P}{\left(M^{2}\right)^{2} k_{B} \Delta v}
$$

となる。ここで, $k_{\mathrm{B}}$ はボルツマン因子, $h$ はプランク定 数である 22,23$)$ 、誘導吸収・放出の定義より，このレー ザーを物質に照射する場合, 物質温度がレーザーの輝度 温度に達するまでは吸収され続けると理解される。ちな みに太陽表面温度でも約6,000 Kであるが、レーザーは 上回る值を容易に達成できる。それゆえに、レーザーに よる金属加工や, 絶縁破壊なども可能になる。また, 高 輝度温度の光は, 物質との強い相互作用が可能であるた め, 当然, 非線形光学効果なども顕著となる.

\section{参考文献}

1) P. D. Ronney: Opt. Eng. 33 (1994) 510.

2) H. Furutani: Oyo Buturi 77 (2008) 1315.

3) D. Graham-Rowe, et. al.: Nature Photonics 2 (2008) 515.

4) T. Taira: Rev. Laser Eng. 37 (2009) 227.

5) T. Taira: O plus E 31 (2009) 1292.

6) M. Tsunekane, T. Inohara, A. Ando, N. Kido, K. Kanehara, and T. Taira: Rev. Laser Eng. 37 (2009) 283.
7) T. Taira and M. Tsunekane: Optronics 28 (2009) 124.

8) T. Taira, M. Tsunekane, T. Fujikawa, M. Ebina, K. Akihama, T, Inohara, A. Ando, N. Kido, and K. Kanehara: J. Combustion Soc. Japan 51 (2009) 288.

9) M. Tsunekane, T. Inohara, A. Ando, N. Kido, K. Kanehara, and T. Taira,: IEEE J. Quantum Electron. 46 (2010) 277.

10) M. Tsunekane, T. Inohara, K. Kanehara, and T. Taira: Advances in Solid-State Lasers: Development and Applications, Mikhail Grishin ed. (INTECH, 2010) pp.195-212.

11) E. Schwarz, I. Muri, J. Tauer, H. Kofler, and E. Wintner: Laser Phys. 20 (2010) 1545.

12) J. J. Zayhowski and C. Dill III: Opt. Lett. 19 (1994) 1427.

13) N. Pavel, J. Saikawa, S. Kurimura, and T. Taira: Jpn. J. Appl. Phys. 40 (2001) 1253.

14) H. Sakai, H. Kan, and T. Taira: Opt. Express 16 (2008) 19891.

15) T. Taira, Y. Matsuoka, H. Sakai, A. Sone, and H. Kan: in Conference on Lasers and Electro - Optics/Quantum Electronics and Laser Science Conference and Photonic Applications Systems Technologies 2006 Technical Digest (Optical Society of America, Washington, DC, 2006) CWF6.

16) S. Hayashi, T. Shibuya, H. Sakai, T. Taira, C. Otani, Y. Ogawa, and K. Kawase: Appl. Opt. 48 (2009) 2899.

17) T. Shiraishi and T. Urushihara: J. Combustion Soc. Japan 51 (2009) 31 .

18) T. Taira: IEEE J. Sel. Top. Quantum Electron. 13 (2007) 798.

19）古谷博秀，稲見昭一，宮田淳也：三井造船技報 199 (2010) 18.

20) T. Uehara, M. Yoda, Y. Sano, N. Mukai, I. Chida, and H. Kato: in Proc. of the 16th Int. Conf. on Nuclear Engineering (ASME, Orlando, Florida, USA, 2008) ICONE16-48202.

21) T. Taira: The Review of Laser Engineering 26 (1998) 723.

22) T. Taira: Systems, devices and materials for the holographic data storage, T. Shimura ed. (CMC books, 2006) p.228.

23) T. Taira: in CLEO/Europe-IQEC (IEEE, Munich, 2007) CA33-MON (2007). CD-ROM

${ }^{*} U(v)$ は, 単位周波数当りの黑体エネルギー密度なので $U(v)=8 \pi h v^{3} / c^{3}\left(e^{h v / k_{B} T_{B}}-1\right)$ となる. 